Emperor Journal of Classical Tamil Studies

www.ejcts.mayas.info

DOI-http://dx.doi.org/10.35338/EJCTS.2019.1105

EJCTS

ISSN: 2582-2977

www.ejcts.mayas.info

மாயாஸ் பதிப்பகம்

Volume - I

Issue - 10

October - 2019

\title{
WATER BODIES AND WATER RESOURCE MANAGEMENT IN CHENNAI CITY
}

\section{R. Mayakkannan}

Department of Commerce, Sri Sankara Arts and Science College, Enathur, Kanchipuram -631561

\section{ABSTRACT}

Water bodies comprise the most profitable environments with huge natural administrations to humanity. These biological communities fill in as life emotionally supportive networks and as natural surroundings for an assortment of creatures including transient feathered creatures for nourishment and haven. Water bodies help in bio-remediation and along these lines viewed as the "kidneys of the scene". Water bodies additionally comprise as crucial parts of the provincial hydrological cycle. Other major biological administrations incorporate surge control, squander water treatment, capturing silt loads, drinking water source, protein generation, and all the more imperatively reviving of aquifers separated from supporting as sinks and atmosphere stabilizers.

Keywords: Water bodies, Water Resource Management, Chennai City

\section{INTRODUCTION}

Now a days working as a wild fauna haven with free. These biological systems are values for instruction and logical undertaking because of rich biodiversity. They additionally upgrade the feel of the scene and bolster many. Today, most urban water bodies including wetlands are truly undermined by transformation to wastelands, infringements as solid structures, infringements of waste through landfills, pollution3, hydrological alterations 4 , and overexploitation of their common resources5. In this section, an itemized expense about the condition of water bodies in Chennai city is investigated through accessible optional information, or, in other words introduced as four contextual analyses featuring four diverse water-related issues in Chennai City. Moreover, a nitty-gritty examination on the view of overall population on water asset administration is attempted to not just investigate the issues identified with water assets administration yet in addition to recognize the general population state of mind towards our rare natural asset, the water.

\section{WATER BODIES IN CHENNAI CITY}

Chennai city comes up short on a perpetual water source, and along these lines, providing food the water prerequisites of the populace remains an enormous test for quite a few years. As indicated by Chennai Metro Water, Chennai gets around 985 million liters for each day from different sources against the required measure of 1,200 MLD. This interest is relied upon to ascend to 2,100 MLD by 20316. This circumstance 
reminds us the way that Chennai will undoubtedly confront water supply deficiencies in the pending years too. As no enormous waterway moves through Chennai, the city has exclusively depended on yearly rainstorm downpours to recharge water supplies. Ground water assets in Chennai are renewed by rain water and the city's normal precipitation is $1,276 \mathrm{~mm}$. Chennai, subsequent to having developed into a city, is presently the Chennai Metropolitan Area for arranging purposes. The CMA has 22 water courses, including three waterways, a channel, and four supply tanks. This likewise incorporates 16 minor conduits. The city has three waterways streaming into the Bay of Bengal, specifically, the Cooum, the Adyar, and the Kosasthalaiyar, which partition the city into north-south sections7. The Buckingham trench associates all the three streams. There are four stores in the city, to be specific, Red Hills, Cholavaram, Poondi and Chembarambakkam, with a consolidated limit of 11,057 mcft8. The Red Hills repository has a limit of 3,300 mcft. The Cholavaram the repository has a limit of $881 \mathrm{mcft}$. The Poondi store has a limit of 3,231 mcft. The Chembarambakkam repository has a limit of 3,645 mcft. Water to the city's occupants is being provided likewise from desalination plants at Nemelli and Minjur; aquifers in Neyveli, Minjur, and Panchetty; Cauvery water from Veeranam lake; Krishna stream from Andhra Pradesh; Poondi supply; and lakes at Red Slopes, Chembarambakkam and Cholavaram9. Given the expanding request of water prerequisites in Chennai city, it remains an essential test for city specialists to source water from numerous sources to disperse water to all kinds of different backgrounds. An ongoing report from Central Water Commission that screens water levels affirm that water circumstance in significant supplies spread crosswise over Tamil Nadu and the other Southern States keep on declining to around 11\% of their aggregate storage 10. This insight is unquestionably not urging to water organizers and overall population. The job of Government Departments in Water Resource Management in Chennai City

The lawmaking power vested with lawmaking body and the administrative shrewdness is fundamental for the key people who are engaged with arrangement make. Anyway, the established law must be executed through the official organ that is through concerned branches of the legislature. What's more, they possess an imperative job to authorize any tenets furthermore, controls in the general public for the welfare of the general population. Here the concerned offices which are significant to the preservation and administration of water bodies and its assets are abridged for our simple comprehension about the official setup administering this zone in the Chennai city.

\section{PUBLIC WORKS DEPARTMENT}

Public Works Department is the executing and keeping up power all the Governance structures and all water system tasks, for example, dams, channels, tanks diverse works, for example, development of structures, streets, spans, ducts, water collecting structures, usage and support of water supply in provincial territories. PWD possesses 85 dams and stores. Among 39,000 tanks in Tamil Nadu, around 10,000 tanks are possessed by PWD. Of the 10,000 tanks, 5,000 tanks are framework tanks encouraged by Riverine channel streams. The rest 5,000 tanks are rain-sustained tanks. These advantages are the hotspot for flooding an aggregate degree of around 69, 00, 000 sections of land. Ground water wells utilized for water system purposes just are 16,44,946 Nos. Water Resources Department is the specific office inside PWD that deals with water asset administration in Tamil Nadu. WRD having tackled the surface water system potential to 95\% (12387 M cum), the Department's primary capacity has swung to be that productive administration, use, and dispersion of rare water assets. Almost around 90 tanks in Chennai Metropolitan region is kept up by WRD. 


\section{R. Mayakkannan}

\section{Chennai City Corporation}

Chennai Corporation oversees 109 lakes in its constraints the land records identifying with water bodies and land effects to recent Panchayat have not been kept up by the Chennai Corporation12. The land and homes of the company have not been ready to recover data on such land for as far back as a couple of years. This has prompt land getting in numerous regions. Before converging with Chennai Corporation each Panchayat has arrived for brushing of creatures, lakes for drinking water and other network needs. Presently every one of the terrains has been wrongfully possessed and the partnership has lost those land packages. This is a reason for worry for the straightforward reason that any loss of terrains that were once utilized for sparing surface water and along these lines bolstered in the restoration of water tables, will influence the status of water in Chennai city for the present and until the end of time.

\section{Chennai Metro Water Supply and Sewage Board}

CMWSSB embraces the onus errand of Water supply and sewage treatment to the city of Chennai and around regions of Chennai. Chennai is one of the metros in India which is reliant generally on ground water supply. Ground water in Chennai is renewed by rain water and normal precipitation in Chennai is $1276 \mathrm{~mm}$. Chennai gets around 985 million liters for every day from different sources against the required measure of 1200 MLD and the interest is relied upon to ascend to 2100 MLD by 2031. The recently developed Minjur desalination plant adds another 100 MLD to the city's developing interest. Starting at 2012, Chennai Metro Water supplies around 830 MLDs consistently to occupants and business foundations. With the development of the company territory in 2011 from $174 \mathrm{sq} \mathrm{km}$ to $426 \mathrm{sq}$ $\mathrm{km}$, which expanded the quantity of wards of the Chennai Corporation from 155 to 200 and the quantity of zones from 10 to 15, Metro Water client base is relied upon to increment by an extra 1.7 million when the new zones are secured. The quantity of region workplaces of Metro Water would likewise be changed to compare with the Corporation's zones. While the current 155 stop workplaces of Metro Water would be decreased to 107, 93 new warehouse workplaces would be included from consolidated zones. At present, every warehouse office serves a populace of around 50,000. Since a few wards have been converged into one, the inclusion of the warehouse office would increment by 20,000 . There are additionally proposition to develop sewage treatment plants in Mangadu and Villivakkam as a major aspect of the plans to fabricate new foundation for the recently blended zones. While CMWSSB keep on investigating choices to guarantee constant arrangement of consumable water to every one of its individuals, the test is just getting heavier and heavier as exhaustion of water bodies keep on becoming significantly further.

\section{Contextual analysis}

Contextual analysis way to deal with research includes a point by point or top to bottom investigation of a specific circumstance instead of a broad factual overview. It is for the most part utilized as a technique to investigate and decide a researchable subject from an extremely wide field of research. While it won't answer an inquiry totally, it will give a few signs and permit advance elaboration and speculation creation regarding a matter. In this investigation, the specialist while looking at surviving writing on water asset administration and administration watched and recognized particular issues relating to water issues in Chennai city. 


\section{Water Scarcity in Chennai City - A Perennial Problem}

Water is one of the world's most valuable assets. Concentrates by worldwide associations like United Nations recommend that half of the total populace will confront intense water deficiency by 2030. This circumstance is all the more so in creating nations like India. In the following two decades, all the real Indian urban communities will run dry, says a World Bank report. Water shortage is higher in beach front locales in examination with the inside parts of India; in seaside regions, the groundwater is saline and not reasonable for drinking, of the 27 Asian urban communities with populace of more than 10 lakh (1 million), Chennai and Delhi have been positioned as the most exceedingly bad performing metropolitan urban areas regarding water accessibility every day, while Mumbai is the second most exceedingly bad entertainer, and Kolkata the fourth most exceedingly bad (see figure 1.2).

Figure 1.1: Water Requirement in Coastal Cities (India), 2008 and 2026

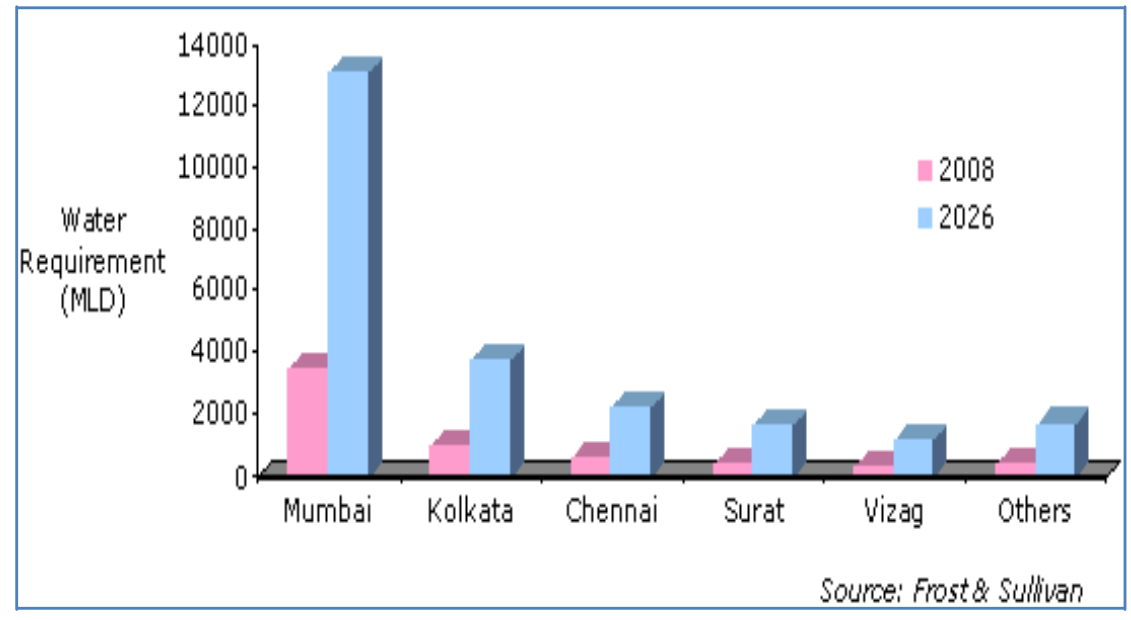

\section{Source: Secondary Source}

Seaside urban areas like Chennai are progressively home to a substantial and developing populace is experiencing the ecological decrease. The high grouping of individuals has delivered numerous monetary advantages, including enhanced transportation joins, mechanical and urban advancement, income from tourism, and sustenance generation. Yet, the joined impacts of blasting populace development and financial and mechanical advancement are undermining the biological systems that give these monetary advantages. Except if governments and clients of waterfront assets make a move, populace weights and the related levels of financial action will additionally corrupt and extreme Chennai's predicament to secure water and condition.

\section{Water Scarcity in Chennai City}

Chennai's water circumstance and water shortage is extreme and has resolved to remain in light of a large group of reasons. Chennai speaks to the fourth biggest metropolitan territory in India representing a populace of 8.7 million out of 2011. Because of fast populace development, troubles in regards to the arrangement of water requests have been emerging. The city keeps on confronting water supply deficiencies and its groundwater levels have likewise been exhausted continuously over the most recent two decades or something like that. Outrageous climate conditions, for example, dry periods and substantial rainfalls have additionally affected the water supply foundation frameworks, in this manner showing the city's failure to adapt to ecological test. The expanding interest for water is as of now telling upon the focused on groundwater assets. 


\section{R. Mayakkannan}

Metro Water has been drawing around 120 MLD from 273 rural wells in Ramarajan Kandigai, Velliyur, Moovur, Pullarambakkam and Karanai in Tiruvallur area. Such a game plan requests enormous ventures, managerial setup and powerful administration components.

Figure 1.3 Capital Costs for Water Infrastructure

\begin{tabular}{|c|c|c|c|}
\hline Infrastructure & $\begin{array}{c}\text { Water Supplied/Recharged } \\
\text { (Million } \mathrm{m}^{3} / \text { year) }\end{array}$ & $\begin{array}{l}\text { Capital Costs } \\
\text { (Million INR) } \\
\end{array}$ & $\begin{array}{l}\text { Unit Costs } \\
\left(\mathrm{INR} / \mathrm{m}^{3}\right)\end{array}$ \\
\hline $\begin{array}{l}\text { New surface storage reservoirs } \\
\text { (Thervoikandigai-Kannankottai Reservoir) }\end{array}$ & 28.31 & 3300 & 117 \\
\hline $\begin{array}{l}\text { Increasing storage capacity of existing reservoirs } \\
\text { (Cholavaram, Porur, Ayanambakkam \& Nemam tanks) }\end{array}$ & 16.08 & 1300 & 81 \\
\hline Desalination (Nemmeli plant) & 36.50 & 8712 & 239 \\
\hline New check dam (Irulipattu check dam) & 0.30 & 62 & 207 \\
\hline Infiltration pond (Anna University pilot project) & 0.000175 & 0.015 & 86 \\
\hline
\end{tabular}

\section{Source: Secondary Source}

At the point when water supply by Chennai Metro water wanes city inhabitants swing up to private providers to connect the broadening hole. There are around 1,500 assembling units that draw waters from ground water sources and oblige Chennai occupants. Around 425 of them are operational in the areas of Chennai, Tiruvallur, and Kancheepuram, where the misuse of ground water assets is at its prime. It is contended that expanding reliance on water tankers and indiscriminate strategies embraced by these tanker administrators will, in the end, add to an acceleration of water emergency, particularly amid summer seasons. Quicker extraction of ground and also surface water assets than the rate of recharging is a disaster really taking shape. With the dependence on water tankers ascending in the course of recent months in the city, Chennai Metro water intends to actualize a GPS-based programmed lorry following framework to check unaccounted tanker trips.

\section{Rain Water Harvesting}

RWH is an exceptionally contemporary arrangement, time-tried and need of great importance to alleviate surges as well as to satisfy our water prerequisites locally. Rainwater is really intended to wind up groundwater so every native need to step up with regards to energize it. For the person, when someone builds a house it is their obligation to deal with the abundance water from that plot of land, which would some way or another go into a tempest water deplete or else make water-logging around the plot. RWH would recharge groundwater as well as enhance its quality and relieve flooding. 5\% of any built-up the region, be it a flat intricate or singular house, whenever utilized for water gathering, can relieve surges and furthermore lessen water bills.

A few towns in Germany have made it compulsory for development tasks to assume liability for their abundance keeps running off or pay more to put weight on tempest water channels. Energize wells can be built in open spaces around tempest water channels. Water in channels can be caught and coordinated to these wells. In territories where open spaces are not accessible, revive wells can dive in the deplete itself under the man-gap with the goal that it very well may be cleaned likewise every now and then. Re-laying of streets according to the normal seepage designs should be completed. Each drop adds to surges, so porous rock or stone-lined parking spots and pathways that can ingest water instead of the concretized floor would likewise help. Also, 
there is no substitute for planting trees in whatever zone is accessible to advance ingestion of water and control run-off of soil.

There is no significant relationship between public participation and water crisis situation in Chennai City.

Table 1.1: Cross-tabulation - Public Participation and Water Crisis

\begin{tabular}{|l|l|c|c|c|}
\hline & Water Crisis & High & Moderate & Total \\
\hline Public Participation & High Participation & $\begin{array}{c}107 \\
(77 \%)\end{array}$ & $\begin{array}{c}32 \\
(23 \%)\end{array}$ & 139 \\
\cline { 2 - 5 } & Low Participation & $\begin{array}{c}34 \\
(55.7 \%)\end{array}$ & $\begin{array}{c}27 \\
(44.3 \%)\end{array}$ & 61 \\
\hline Total & 141 & 59 & 200 \\
\hline
\end{tabular}

\section{Source: Primary Data}

Table shows cross-tabulation results to determine whether there is any association (relationship) between public participation and water crisis in Chennai city. Greater majority of respondents (77\%), who have reported about higher participation also have reported severe water crisis in the city and vice versa. To statistically determine the significance of this relationship, Chi-square test was done.

Table 1.2: Chi-Square Tests Results - Public Participation and Water Crisis

\begin{tabular}{|l|c|c|c|c|c|}
\hline & Value & Df & $\begin{array}{c}\text { Asymp. } \\
\text { Sig. (2-sided) }\end{array}$ & $\begin{array}{c}\text { Exact } \\
\text { Sig. (2-ided) }\end{array}$ & $\begin{array}{c}\text { Exact } \\
\text { Sig. (1-sided) }\end{array}$ \\
\hline Pearson Chi-Square & $9.197^{\mathrm{a}}$ & 1 & .002 & & \\
\hline Continuity Correction & 8.204 & 1 & .004 & & \\
\hline Likelihood Ratio & 8.877 & 1 & .003 & & .002 \\
\hline Fisher's Exact Test & & & & .004 & \\
\hline Linear-by-Linear Association & 9.151 & 1 & & & \\
\hline N of Valid Cases b & 200 & & & & \\
\hline \begin{tabular}{l} 
a. 0 cells (.0\%) have expected count less than 5. The minimum expected count is 18.00. \\
\hline
\end{tabular} \\
b. Computed only for a 2x2 table
\end{tabular}

\section{Source: Primary Data}

Table shows the results of chi-square tests, which confirm significant relationship between public participation and water crisis situation. As evident, the estimated p-value is 9.197, which is statistically significant at 0.05 level of significance. Therefore, the null hypothesis is rejected. It is therefore affirmed that water related problems continue to scale up, public participation in matters affecting water resources are bound to increase as well.

There is no significant relationship between public awareness on water environment and water crisis in Chennai city.

Table 1.3: Cross-tabulation - Public Awareness and Water Crisis

\begin{tabular}{|l|c|c|c|c|}
\hline & Public Awareness & Low & High & Total \\
\hline \multirow{3}{*}{ Water Crisis } & High & $85(60.3 \%)$ & $56(39.4 \%)$ & 141 \\
\cline { 2 - 5 } & Low & $17(28.8 \%)$ & $42(71.2 \%)$ & 59 \\
\hline Total & 102 & 98 & 200 \\
\hline
\end{tabular}

Source: Primary Data 


\section{R. Mayakkannan}

Table 1.3 shows cross-tabulation results to determine whether there is any association (relationship) between public awareness on water / environment water crisis in Chennai city. Majority of respondents $(60.3 \%)$, who have reported low awareness to water rights and environment protection also have reported severe water crisis in the city and vice versa. To statistically determine the significance of this relationship, Chi-square test was done.

\section{CONCLUSION}

Water shortage is a reality and has just prompted a developing number of contentions around the world. In India, various master councils were built up to take a gander at the issue and distinguish conceivable arrangements, yet there has been no advancement. In Chennai, water shortage is serious. Lacking water supply to meet the quickly developing requests, unsustainable groundwater, and surface water utilization, expanding water contamination and uneven arrangement of solid, fair and secured water supply are issues that inhabitants of Chennai look all the time. Water assets both surface and ground are quickly waning fundamentally because of the botch of water assets, albeit over-pumping and contamination are likewise noteworthy givers. Water lost through breaks in the appropriation systems swelled utilization as a result of supply being constrained to just a couple of hours daily, the absence of mindfulness about water preservation, and the absence of political will, all add to the issue, making it a ceaseless issue to address. In any case, this situation requires not to proceed. The government ought not to loosen weight in advancing water energizing measures, incorporating desilting tanks alongside the development of revive shaft or revive bore wells, advancing RWH through wells.

\section{REFERENCE}

1) Ahmad, S., \& Simonovic, S. P. (2004). Spatial system dynamics: New approach for simulation of water resources systems. Journal of Computing in Civil Engineering, 18(4), 331-340.

2) Alberta Environment (2002). Water Resources Management Model Computer Program Description. Southern Region Resource Management Branch, Alberta Environment.

3) Alberta Environment. South Saskatchewan Regional Plan: Water Quantity and Quality Modeling Results. Alberta Environment, 2010.

4) Alberta Environment. South Saskatchewan River Basin Water Management Plan Phase Two: background Studies. Alberta Environment, $2003 \mathrm{~b}$.

5) Andrews, E. S., F. I. Chung, and J. B. Orlin (1993), Multilayer, priority based simulation of conjunctive facilities, J. Water Resour. Plann. Manage., 118(1), 32-53

6) www.Chennai corporation.in 